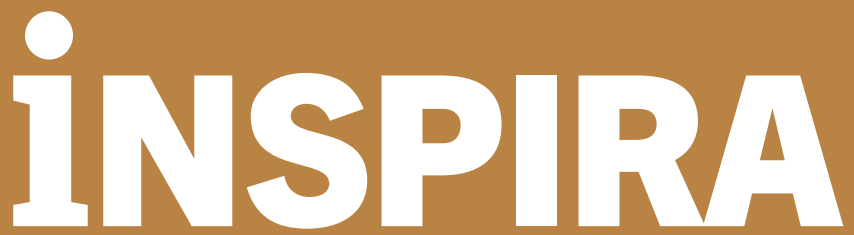

Tidsskrift for anestesi-, operasjon- og intensivsykepleiere

Forskningsartikler | Vol. 16, No. 1, 2021, s. 1-15

\title{
Intensivsykepleiernes erfaringer med teoretisk og praktisk opplaring for å gjennomføre inhalasjonssedering til respiratorpasienter $i$ intensivavdelingen
}

\author{
Wenche Orseth \\ RN, intensivsykepleier, Master i Helse og Sosialfag, Intensiv- og overvåknings avdelingen Molde Sjukehus, Norge \\ E-post: wenche.orseth@hotmail.com \\ Hildegunn Sundal \\ RN, PhD, Førsteamanuensis, Høgskolen i Molde, Norge
}

\section{Sammendrag}

Bakgrunn: Intensivpasienter som ligger på respirator kan ha behov for sedering. De mest brukte medikamentene kan føre til komplikasjoner som delir og forlenget tid på respirator. I 2005 kom det et nytt filter som kan administrere sedative flyktige gasser som sevofluran og isofluran til respiratorpasienten i intensivavdelingen. Dette filteret heter Anaesthetic Conserving Device (AnaConDa). Disse gassene akkumuleres ikke i kroppen og kan redusere forekomsten av delir, føre til raskere oppvåkningstid og kortere tid på respirator. Det har medført at intensivsykepleiere må lære en ny sederingsmetode.

Hensikten med studien var å unders $\varnothing$ ke intensivsykepleierens erfaringer med teoretisk og praktisk opplæring for å gjennomføre inhalasjonssedering til respiratorpasienter i intensivavdelingen.

Metode: Studien hadde et kvalitativt design, med semi-strukturerte intervjuer av 6 intensivsykepleiere som hadde erfaring med opplæring og administrering av sevofluran og isofluran via AnaConDa. Intervjumaterialet ble transkribert og analysert etter Malteruds tekstkondensering i fire trinn.

Resultater: Studien har tre hovedfunn: erfaringer knyttet til opplæring, erfaringer knyttet til gjennomføring og erfaringer etter opplæring var avsluttet.

Konklusjon: Studien viser at intensivsykepleierne opplevde opplæring med teoretisk undervisning sammen med å $ø$ ve praktisk uten respiratorpasient som nødvendig, og at støtte under gjennomføring av inhalasjonssedering på pasient var viktig. Behandling med inhalasjonsgass administrert via AnaConDa til respiratorpasienter ga stort sett $\varnothing$ nsket effekt. Det motiverte dem til å fortsette å utøve for å bli trygg på bruken av AnaConDa.

Nøkkelord: AnaConDa; inhalasjonssedering; intensivavdeling; intensivsykepleier 


\section{Abstract}

Intensive care nurses' experience of theoretical and practical training in administering inhalation sedation to respiratory patients in intensive care units

Background: Mechanically ventilated patients in the intensive care unit may need sedation. The most used medicines can lead to complications as delirium and prolonged time on the ventilator. A new filter arrived in 2005 , which could administrate volatile gasses like sevoflurane and isofluran to the mechanically ventilated patient in intensive care unit. The filter is named Anaesthetic Conserving Device (AnaConDa). These volatile gasses do not accumulate in the body, and may reduce the appearance of delirium, shorten the awakening time and time on the ventilator. This means that critical care nurses must learn a new sedation method.

The purpose of this study was to explore intensive care nurses' experience with theoretical and practical learning to administrate volatile sedation to the mechanically ventilated patients in the intensive care unit.

Method: The study had a qualitative design and used semi-structured interviews of 6 critical care nurses who had experienced the administration of sevoflurane and isoflurane via AnaConDa. The interview material was transcribed and analyzed by Malterud's text condensation in four steps.

Results: The study has three main findings: experiences related to training, experiences related to implementation and experiences after training were completed.

Conclusion: The study shows that critical care unit nurses experienced that learning theoretical instructions along with practical training is necessary, and that support during the implementation of inhalation sedation on the patient is important. They experienced that the treatment with volatile gasses administrated via AnaConDa to mechanically ventilated patients mostly gave the wanted results. This was a motivation factor to proceed in performing to feel safe with the administration of AnaConDa.

Keywords: AnaConDa; inhaled sedation; intensive care unit; critical care nurse

\section{Introduksjon}

Hos en intensivpasient kan det foreligge begynnende eller oppstått akutt svikt i et eller flere vitale organer som forventes å være helt eller delvis reversibel (1). Noen intensivpasienter behøver ikke pustehjelp av en respirator, men for andre kan det være nødvendig. Respiratorbehandling kan kreve tilførsel av medikamenter slik at en ikke er i helt våken tilstand under behandlingen, sedasjon. Graden av sedering kan være fra lett til tung, at pasienten sover lett eller er i kunstig koma (1). De vanligste sedasjonsmedikamentene til respiratorpasienter idag er benzodiazepiner som midazolam og lorazepam, propofol og a2-agonister som clonidin og dexdor. Målet med sedering er at pasienten skal ha minst mulig ubehag, smerter eller angst. Et tilstrekkelig sedasjonsnivå optimaliserer ventileringen, og minsker risikoen for at viktig utstyr blir dratt ut eller $\varnothing$ delagt. Den vanligste kombinasjonen av medikamenter til pasienter som skal ligge på respirator over tid er midazolam (benzodiazepine) sammen med et smertestillende medikament. Studier viser at benzodiazepiner gir $\varnothing \mathrm{kt}$ risiko for delir, motorisk uro og tap av minner fra intensivoppholdet (2-4).

Intensivdelirium er vanlig hos intensivpasienten, og vil påvirke pasientens opplevelser. En studie gjort av Ely mfl. viser at over $80 \%$ av intensivpasientene utviklet delir i løpet av oppholdet. Delir, motorisk uro, angst og tap av minner er faktorer som vanskeliggjør 
oppvåkningsfasen og samarbeidet om respiratoravvenningen og ekstubasjonen (5). Konsekvensen er $\varnothing \mathrm{kt}$ tid på respirator med påfølgende risiko for komplikasjoner som for eksempel ventilator assosiert pneumoni (VAP) og økt liggetid på intensivavdeling. Dette gir $\varnothing \mathrm{kt}$ belastning for pasienten og pårørende, og er i tillegg en stor utgift for samfunnet (3-5). Pasientens situasjon med forekomst av VAP og tid på respirator kan reduseres med perioder hvor pasienten er mer våken og med å benytte repeterende ABCDEF-bundle unders $\varnothing$ kelser og tiltak, som er en integrert, interprofesjonell tilnærming for symptomhåndtering hos pasienten gjennom intensivbehandling $(6,7)$.

Intensivpasienter som blir respiratorbehandlet, og som utvikler akutt delirium, sepsis og/eller akutt lungesviktsyndrom (ARDS) er i risikosonen for å utvikle Post Intensive Care Syndrome (PICS) (8-11). PICS har ingen vedtatt definisjon, men Mikkelsen mfl. (11) viser til enighet hos de fleste klinikere om at PICS beskriver en ny eller forverret dysfunksjon i ett eller flere av følgende funksjonsområder: kognitiv funksjon, psykisk funksjon, fysisk funksjon, hos pasienten etter en intensivbehandling. Om pasienten utvikler PICS vil dette kunne være en stor belastning både for pasienten selv og pårørende. I tillegg vil det føre til $\varnothing$ kte kostnader for samfunnet $(10,11)$. Dette viser viktigheten av tilpasset sedasjon.

\section{Sevofluran og isofluran}

$\AA$ sedere pasienten under respiratorbehandlingen er sentralt for hvordan intensivpasienten har det (2). Under operasjon har man i mange år brukt flyktige gasser som sevofluran og isofluran for å inhalasjonssedere pasienter. Dette er flyktige gasser som ikke akkumuleres i kroppen. Det vil si at faktorer som nyre- eller leversvikt, som vanligvis forsinker utskillelse av medikamenter gitt intraven øst, eller store doser gitt på grunn av ønsket om dyp sedasjon, ikke forlenger oppvåkningsfasen i særlig grad. Gassene gir heller ikke den samme risiko for delir som benzodiazepiner. I tillegg kan konsentrasjonen av gassene måles i ekspirasjonen til pasienten slik at sedasjonsnivået hele tiden monitoreres. Da er det lettere å tilpasse riktig dose. Dette er ikke mulig ved bruk av intravenøs sedering. På operasjonsstuen blir disse gassene administrert via et stort anestesiapparat og krever en viss standard på ventilasjonsanlegget, så det er lite brukervennlig på en intensivavdeling. Ny apparatur har blitt utviklet og gjort det mulig å benytte gass som sedasjon ved respiratorbehandling til pasienter i intensivavdelingen (12).

\section{Anaesthetic Conserving Device (AnaConDa)}

Ideen om å utvikle en administrasjonsmetode til bruk i intensivavdelingen kom på midten av 1990-tallet. Den første versjonen av Anaesthetic Conserving Device (AnaConDa) ble dokumentert i bruk i 2001. Den har siden blitt utviklet og forbedret. AnaConDa er et filter som omgjør flytende gass til inhalasjonsgass. Den kobles på respiratorslangene nærmest inn til pasienten, og skal ved små justeringer passe alle respiratorer og slanger. AnaConDa har samme egenskaper som et HME-filter (Heat and Moisture Exchanger), både som et bakterie- og fuktfilter. Når AnaConDa er koblet på respiratorslangene, er en infusjonsslange fra AnaConDa koblet til en sprøytepumpe som er trukket opp med 
flytende gass, og AnaConDa-filteret omgjør den flytende gassen til inhalasjonsgass. Opptrekking av gass må skje under en avtrekksvifte, og ferdig opptrukket sprøyte må ikke utsettes for kulde, sollys eller andre varmeelementer da den er sensibel for varme og kulde. På en egen monitor leses fet-verdien (konsentrasjonen av gass) og $\mathrm{CO}_{2}$ i ekspirasjonsluften til pasienten. Det går en egen slange fra AnaConDa som kobles til monitoren. For at resterende gass i ekspirasjonsluften ikke skal komme ut i rommet, kobles det en slange på ekspirasjonsporten til respiratoren som går ned i et kullfilter som innkapsler sedasjonsgassene (12).

\section{Intensivsykepleierens ansvarsområde med behov for opplæring}

Både oppkobling av AnaConDa til respiratorslangene, titrering av sedasjonsgassdose, observasjon og dokumentasjon av sedasjonsnivå hos intensivpasienten, skifte av sprøyter, AnaConDa og kullfilter er sykepleieoppgaver. Sackey mfl. påpeker at det tidligere har vært kun anestesipersonell som har administrert inhalasjonsgass, slik at dette er helt nytt for personell på intensivavdelingen. Dette mente de kunne øke risikoen for feildosering, feil i monitoreringen, lekkasje ved håndtering av gassen og generell motstand mot å bruke det, men det viste seg at 6 år etter opplæringsperioden hadde de ikke hatt en eneste uheldig hendelse. De understreker dog viktigheten av god opplæring (2). Det er derfor interessant å gjøre undersøkelser av intensivsykepleiers erfaringer med det å få opplæring og benytte inhalasjonssedering i respiratorbehandlingen av intensivpasienten.

\section{Tidligere forskning}

Det er forsket mye på bruken av sevofluran og isofluran under operasjon, og det finnes også en del forskning ved bruk av AnaConDa til respiratorpasienter i intensivavdeling. Forskningen på respiratorpasientene går på effekt, kontraindikasjoner, utviklingen med et historisk perspektiv og fordeler versus ulemper (12-14). Studiene viser at bruk av sevofluran/isofluran reduserer oppvåkningstiden og ekstubasjonstiden til sammenligning med midazolam/propofol hos respiratorpasienter. Til tross for dette kan ikke studiene vise til redusert sykehusopphold eller mortalitet. Studiene kan ikke vise til signifikant forskjell i forekomsten av delir blant disse to pasientgruppene, kun en antydning i fav $\varnothing \mathrm{r}$ av å benytte sevofluran/isofluran $(12,13)$. En meta-analyse fra 2017 bygd på 13 studier antyder at inhalasjonssedering kan ha en beskyttende effekt på hjertemuskulaturen etter hjerteoperasjoner, men på grunn av få deltagere i studiene er det behov for mer forskning (14).

Det er ikke avdekket tidligere studier om intensivsykepleieres erfaringer med opplæring og gjennomføring av inhalasjonssedering i respiratorbehandlingen av intensivpasienter.

\section{Hensikt}

Hensikten med studien var å unders $\varnothing$ ke intensivsykepleieres erfaringer med teoretisk og praktisk opplæring for å gjennomføre inhalasjonssedering, via AnaConDa, til respiratorpasienter i intensivavdelingen. Inhalasjonsgassene er sevofluran og isofluran. 


\section{Teoretisk perspektiv}

Filosofen Donald Schöns teori om den reflekterende praktikeren kan gi forståelse av læring og utøvelse i en praksis. Han deler praksisfeltet inn i overkommelige problemer som lar seg løse med kjente handlingsteorier - en vet hva en skal gjøre og spontant utfører det. I andre situasjoner har man mer komplekse problemer som kan virke uløselige og som har ukjente, uforutsette, usikre og konfliktfylte overraskelser ved seg. Det er de komplekse problemene som har mest menneskelig relevans. Schön bygger sin teori rundt tre kategorier: viten/kunnskap i handling, refleksjon i handling og refleksjon etter/ over handling (15). Aristoteles' tre kunnskapsformer episteme (teoretisk, vitenskapelig kunnskap/viten), techne (ferdighetskunnskap) og fronesis/klokskap (praktisk kunnskap/ visdom) er ulike kunnskapsformer som er i spill i læring og utøvelse av en praksis (16). Også filosofen Martha Nussbaums tenkning om forholdet mellom følelser og fornuft ved læring gjennom yrkesutøvelsen kan gi forståelse til studiens tema (17).

\section{Metode}

Studien hadde et kvalitativt design med en hermeneutisk tilnærming for å innhente intensivsykepleiernes subjektive erfaringer med opplæring for å gjennomføre inhalasjonssedering på respiratorpasienter. Ved å benytte en hermeneutisk tilnærming fikk man en helhetlig forståelse av intensivsykepleiernes erfaringer, tanker og følelser, der forståelse og fortolkning ut fra den hermeneutiske sirkel med del-helhet var sentralt. Innenfor hermeneutikken er forståelsen og fortolkningen hovedfokus, der en veksler mellom å forstå helhet og del, en bevegelse frem og tilbake. Grunnlaget for forståelsen blir bygd opp av erfaringer, forforståelse og kultur (18-20).

\section{Utvalg}

For å kunne svare på studiens hensikt ble 6 intensivsykepleiere inkludert og intervjuet. De ble rekruttert ved en større intensivavdeling, der en utnevnt kontaktperson rekrutterte dem etter at studien hadde fått innvilget tillatelse. Ved avdelingen hadde det blitt gjennomført fagdager med opplæring av alle intensivsykepleierne for å implementere inhalasjonssedering til respiratorpasienter. Opplæringen besto av teoretisk gjennomgang av fordelene og ulempene med gassene, hvilke pasienter de er spesielt gunstige for og hvilke pasienter som ikke bør få inhalasjonssedering. I tillegg var det en kort praktisk gjennomgang av utstyret. Inhalasjonsgassene som ble benyttet var sevofluran og isofluran, administrert via AnaConDa. Informantene ble rekruttert fra dette universitetssykehuset der det hadde gått mer enn 3 år siden implementering av sederingsmetoden. Inklusjonskriteriene var intensivsykepleiere som hadde jobbet med inhalasjonssedering i minimum 1 år, og som hadde jobbet på intensivavdeling med respiratorpasienter i minimum 5 år.

\section{Etiske vurderinger og godkjenninger}

Det ble utarbeidet et informasjonsskriv med samtykkeerklæring til å delta i studien, der det ble vektlagt frivillighet, konfidensialitet, det å kunne trekke seg fra studien og å delta 
gjennom intervju. Studien ble godkjent av Norsk senter for forskningsdata (NSD) (21). Etiske overveielser som en som forsker må ivareta var knyttet til egen forforståelse og det å møte informantene med åpenhet i intervjusituasjonen (22).

\section{Datasamling}

Det ble benyttet semi-strukturerte dybdeintervjuer. Det ble utarbeidet en intervjuguide som fungerte veiledende, der sentrale tema var teoretisk undervisning og praktisk opplæring, erfaringer ved oppstart av behandling, under behandling og ved avslutning av behandling og opplevd pasient komfort. Intervjuene ble utført på arbeidsplassen til intensivsykepleierne og varte i $25-40$ minutter.

\section{Analyse}

Intervjuene ble transkribert ordrett. Det ble benyttet tilnærmet Kirsti Malteruds analysemetode med tekstkondensering, som er en 4-trinns analysemetode. Malterud argumenterer for at analysemetoden kan benyttes ved ulike forskningstilnærminger, som inkluderer en hermeneutisk tilnærming. Basert på den hermeneutiske sirkel veksler en mellom å forstå og fortolke ut fra helhet og del i analysen, en går frem og tilbake i analysen mot endelige tema og subtema. Hvert intervju ble i første trinn lest gjennom for å få et helhetsinntrykk og for å oppdage foreløpige tema. Så ble teksten i andre trinn lest linje for linje for å oppdage meningsbærende enheter og sortere disse i de foreløpige temaene som ble til kodegrupper. I hver kodegruppe ble det i tredje trinn utarbeidet subgrupper som utgangspunkt for kondensering av de meningsbærende enhetene (tabell 1). Til slutt ble det i fjerde trinn utarbeidet en analytisk tekst ved hjelp av fortolkning, abstraksjon og sammenfatning av kondensatene innen hver kodegruppe og subgrupper. Kodegruppe og subgrupper ble deretter til endelige tema og subtema (19). Funnene består av tre tema og åtte subtema (tabell 2).

\section{Studiens gyldighet og relevans}

Funnene kan være gyldige og ha relevans for tilsvarende intensivavdelinger der en enten vurderer å innføre eller har innført inhalasjonssedering til respiratorpasienter. Gyldige funn for utvalget av informanter ivaretas gjennom inklusjonskriteriene der informantene skal ha erfaring med innføringen og bruken av inhalasjonssedering til respiratorpasienter,

Tabell 1: Eksempel på analysetrinn

\begin{tabular}{llll}
\hline Tema & Meningsenheter & Subtema & Kondensat \\
\hline Erfaringer & Vi gjennomgikk hva inhalasjonssedasjon & Teoretisk & Undervisning om \\
knyttet til & er, hvilke pasienter det kan benyttes & undervisning & inhalasjonssedering, til hvilke \\
opplæring & på, hvordan det kobles opp og hvilke & og praktisk & pasienter, oppkobling og \\
& bivirkninger. Men jeg har bare hatt den ene & gjennomgang & bivirkninger. \\
& gjennomgangen (informant 3). Jeg husker at & & Ikke tilstrekkelig (informant 3). \\
& $\begin{array}{l}\text { det ble veldig fjernt å se på prosedyren fordi } \\
\text { en hadde ikke sett den i bruk. (informant 1). }\end{array}$ & Fjernhet ved bare å se prosedyren \\
& & uten å se den i bruk. (informant 1). \\
\hline
\end{tabular}


Tabell 2: Oversikt over tema og subtema

\begin{tabular}{ll}
\hline Tema & Subtema \\
\hline Erfaringer knyttet til opplæring & Teoretisk undervisning og praktisk gjennomgang \\
& $\varnothing v e$ uten pasient \\
Erfaringer knyttet til gjennomføring & Trygghet for egen helse \\
& A prøve og feile med støtte, for å bli trygg \\
& Pasienten har god effekt, stort sett \\
Erfaringer etter at opplæring var avsluttet & Tydeligere retningslinjer for bruk \\
& Utfordrende pasientsituasjoner \\
& Nok erfaring like trygt \\
\hline
\end{tabular}

men flere informanter kunne gitt større bredde i erfaringene. Studiens analyseprosess ble gjort transparent ved å vise eksempel på analysetrinnene (tabell 1) (19).

\section{Funn}

Analysen ga tre hovedfunn: erfaringer knyttet til opplæring, erfaringer knyttet til gjennomføring og erfaringer etter at opplæringen var avsluttet.

\section{Erfaringer knyttet til opplæring}

Teoretisk undervisning og praktisk gjennomgang

Intensivsykepleierne erfarte det nødvendig å ha en teoretisk undervisning om inhalasjonssedering og praktisk gjennomgang av utstyr for å kunne starte behandling og vedlikeholde den. Det intensivsykepleierne erfarte å huske av den teoretiske og praktiske gjennomgangen på fagdagene var forskjellig. Noen husket i detalj hva som var gjennomgått og oppfattet dette som tilstrekkelig, mens andre oppfattet informasjonen som utilstrekkelig og kunne i liten grad gjengi innholdet.

\section{$\emptyset$ ve uten pasient}

$\AA \varnothing$ ve praktisk uten respiratorpasient på oppkobling av utstyr og ha øvingsutstyr lett tilgjengelig i avdelingen var viktig og ga en tryggere opplevelse ved oppstarten. Det var betydningsfullt å få repetert undervisningen og de praktiske фvelsene flere ganger, helst sammen med en ressursperson. Tiltak som simulering og mer undervisning til de sykepleierne som hadde en koordinatorfunksjon i avdelingen var $\varnothing$ nsket av intensivsykepleierne. A lese en prosedyre med flere ukjente navn og utrykk, uten å ha sett den i bruk, var utilstrekkelig. En mer forklarende prosedyre med bilder og en systematisk fremstilling gjorde at intensivsykepleierne klarte å koble opp utstyret selv, til tross for lite erfaring. Dette var viktig siden tiden mellom opplæring og gjennomføring på pasient, og mellom hver pasient, kunne bli for lang: «...at du hele tiden har et sted hvor du kan hente ut informasjon slik at du raskt er tilbake på et akseptabelt kunnskapsnivå. Det er viktig» (informant 2). 


\section{Erfaringer knyttet til gjennomføring Trygghet for egen helse}

Trygghet for egen helse grunnet fare for gasslekkasje i pasientrommet gjorde at intensivsykepleierne savnet informasjon om ventilasjonen på avdelingen var god nok, og hvordan helsen ble påvirket hvis de ble utsatt for gass over lengre tid. De hadde en forståelse av risiko for lekkasjer som beror på menneskelige feil og feil på utstyret. Hvordan gasslekkasjen håndteres i ettertid var viktig for tryggheten: «Det blir sånn at vi må sjekke koblingene enda nøyere. Da har vi lært det» (informant 6).

Etter hvert hadde informasjon om bruk av gassene blitt lettere tilgjengelig, og det var utført målinger i pasientrommene som bekreftet at det er god nok ventilasjon. Dette hadde bidratt til mer trygghet.

\section{Å prøve og feile med støtte, for å bli trygg}

A starte opp med inhalasjonssedering på respiratorpasient innebar å prøve og feile for å få erfaringer på godt og vondt. Intensivsykepleierne erfarte at oppstarten med inhalasjonssedering kunne bli for brå; plutselig skulle behandlingen startes på en pasient. Dette skapte utrygghet og stress. Å oppleve mestring ga trygghet og var viktig for å få en god start slik at de turte å prøve mer, og det å være to intensivsykepleiere i pasientsituasjonene opplevdes tryggere. Ulempen med en ny sedasjonsmetode var at det ikke nødvendigvis var tilgjengelig andre med erfaring som de kunne støtte seg til. Det var likevel ikke så viktig om den andre hadde så mye mer erfaring, men at de var to som kunne tenke høyt sammen.

Underveis i pasientens forløp med inhalasjonssedering var det viktig for intensivsykepleierne å ha nok hjelp og informasjon. Det å ha tilgjengelig støtte, spesielt i begynnelsen og helst fra en ressursperson eller fra noen med mer erfaring, var viktig. Det var de viktigste faktorene som skilte mellom hva som opplevdes trygt og utrygt. Likevel var det slik at når noe er nytt, så måtte de være forberedt på å lære underveis - de «hadde det ikke i fingrene». Men etterhvert fikk noen mer erfaring og følte seg tryggere, da kunne de gi støtte:

«Jeg trøster meg med at det alltid er noen å spørre. Eller at vi er to som føler oss like dumme, da går det bra»

(informant 6)

\section{Pasienten har god effekt, stort sett}

Erfaringen var at pasientene hadde god effekt av sederingsmetoden og at den ga en mer kontrollert pasientsituasjon, både respiratorisk og sirkulatorisk. Intensivsykepleierne erfarte at riktig sedasjonsnivå som oftest ble oppnådd kjappere i tid. De våknet også raskere opp etter inhalasjonssedering enn med intraven øs sedering, siden gassene ikke ble akkumulert i kroppen. Om pasientene ble mindre deliriske var vanskelig å uttale seg om, men intensivsykepleierne erfarte at pasientene var roligere ved oppvåkningen. Pasienter som var vanskelige å sedere fikk intravenøs sedering i tillegg til inhalasjonssedering, og da ble også grunnlaget for å uttale seg om forskjeller mellom de to metodene 
borte. Erfaringen var også at noen pasienter lå minst et døgn med intaven øs sedering etter avsluttet inhalasjonssedering, før de kunne ekstuberes. Inntrykket var at pasienten hadde det bra med inhalasjonssedering, mye på grunn av at de ble godt nok sederte og dermed aksepterte behandlingen godt. Dette opplevdes som et bedre alternativ enn at relakserende medikamenter ble lagt til tradisjonell intraven øs sedering, for da ble kun deres evne til å motarbeide respiratoren fjernet.

Enkelte pasientgrupper, som f.eks. de med rusproblematikk, kunne ha spesielt gunstig effekt av inhalasjonssedering på grunn av deres høye toleranse for blant annet opioider og benzodiazepiner. De opplevdes mer stabilt sederte uten å få store mengder medikamenter, og dette kunne igjen bidra til redusert liggetid på respirator. Også bronkospastiske pasienter hadde god effekt av behandlingen, siden den hadde en bronkodilaterende effekt i tillegg til at den ga et tilfredsstillende sedasjonsnivå. «Du følte at du nesten fullernærte pasienten med propofol til slutt. Han pressa så han ble blå og ikke noe volum, og du bagget. Han ble lagt på gass når jeg hadde gått hjem. Da jeg kom tilbake neste dag var alt meget bedre. Han hadde veldig effekt av det» (informant 6).

Det var likevel trygt å ha intravenøs sedering i nærheten hvis pasienten ble stresset. Intensivsykepleierne følte seg tryggest på intraven øs sedering, men valgte det som var best for pasienten, de satte egen utrygghet til side og utførte metoden: «Det viktigste er at pasienten aksepterer behandlingen, og at han kan ha det greit der han ligger, det er jeg opptatt av» (informant 2).

\section{Erfaringer etter at opplæring var avsluttet}

\section{Tydeligere retningslinjer for bruk}

Det var behov for tydeligere retningslinjer for når inhalasjonssedering skal brukes, fordi dette kunne føre til mer forutsigbarhet. Intensivsykepleierne uttrykte at behandlingen da kunne bli brukt på flere pasienter, og dermed gi mer mengdetrening. Informasjon om normalverdier for tilstrekkelig sedering og hvilke verdier som er viktigst å passe på, var sentralt å ha kunnskap om. «De verdiene jeg leser av på monitoren. Jeg måtte bare lese i bruksanvisningen, se hvor skal de ligge og jeg måtte se på pasienten. Det var litt skummelt til å begynne med» (informant 4).

Intensivsykepleierne opplevde store forskjeller i egne forutsetninger for å lære nye behandlingsformer. Det ble vanskelig å komme i mål med nok undervisning til alle. Da var det viktigst å sikre pasientsikkerheten, og ha støttefunksjon til de som erfarte å trenge det. Å ha noen års erfaringer med respiratorpasienter før utøvelsen av inhalasjonssedering erfares som en fordel, nettopp fordi det utøves på de dårligste pasientene: «Skal en ikke ha noen år på baken og ha litt erfaring med å håndtere en dårlig intensivpasient før en begynner både med NO-gass og AnaConDa gass?» (informant 3).

\section{Utfordrende pasientsituasjoner}

A begynne med inhalasjonssedering til de krevende og dårligste respiratorpasientene utfordret intensivsykepleiernes oppfølging og håndtering av disse pasientene, der de sto 
med ryggen mot veggen, siste håp. Det var nytt medikament, nytt utstyr, det var gitt for lite informasjon og ingen var erfarne. Disse pasientene var krevende selv med kjente sederingsmetoder, og når det kom inn usikre elementer, skapte det stress. De opplevde å ikke gi god nok medisinsk behandling, de fikk ikke fulgt opp pasienten godt nok og oppnådde ikke læringsutbytte selv av å benytte inhalasjonssedering som metode. Det var også vanskelig å sammenligne inhalasjonssedering med annen sedering. Erfaringen var også at legene på vakttid ikke hadde tilstrekkelig kunnskap om inhalasjonssedering til respiratorpasienter. Derfor var det viktig at intensivsykepleierne hadde en god prosedyre som sikret rutinene rundt behandlingen. Legenes utilstrekkelige kunnskap gjorde at det var vanskeligere å snakke sammen for å avklare pasientsituasjonene.

\section{Nok erfaring like trygt}

Nok erfaring med inhalasjonssedering gjorde det trygt for intensivsykepleierne og pasienten, mens manglende erfaring og usikkerhet hos både intensivsykepleier og lege på vakttid gjorde at metoden ble valgt bort. Intensivsykepleierne var de som koblet opp og utførte behandlingen, og da var det lettere å velge bort og i hvert fall ikke foreslå behandlingen når de hadde liten eller ingen erfaring. Med utrygghet kom også feil: «Det dukker opp småfeil som kanskje ikke har store konsekvenser for pasienten i det store og hele» (informant 2).

Da intensivsykepleierne hadde fătt gjort prosedyren noen ganger følte de trygghet, nettopp fordi de fikk erfaringer med respiratorpasienter som får denne sedasjonsbehandlingen. Terskelen for å starte med gass var større hvis den intravenøse sederingen fungerte, men med større grad av trygghet kunne dette endre seg: «Det har tatt mange år før jeg kan si at nå kan jeg det skikkelig og er trygg på å bruke det» (informant 1).

\section{Diskusjon}

Hensikten med studien var å undersøke intensivsykepleieres erfaringer med teoretisk og praktisk opplæring for å gjennomføre inhalasjonssedering, via AnaConDa, til respiratorpasienter i intensivavdelingen. Erfaringene til intensivsykepleierne med at respiratorpasientene responderte positivt på inhalasjonssedering i denne studien kan sees i sammenheng med Farrell mfl. (12) og Jerath mfl. (13), som viser redusert oppvåkningstid og ekstubasjonstid ved å bruke sevofluran/isofluran til sammenligning med midazolam/ propofol. Studier kan ikke vise til signifikante forskjeller i forekomsten av delir mellom disse to pasientgruppene, der inhalasjonssedering kontra intravenøs sedering benyttes $(12,13)$.

\section{Å oppnå kunnskap ved teoretisk skolering og øvelse}

Behovet for teoretisk skolering for så å øve uten respiratorpasient på prosedyren med inhalasjonssedering i denne studien understreker verdien av praktisk trening når noe nytt skal læres. Intensivsykepleierne uttrykte at de ikke hadde det i fingrene, og dermed manglet de den spontane viten/kunnskap i handling i lys av Schöns tenkning om den 
reflekterende praktiker (15). Schön forstår viten/kunnskap i handling som vår erfaringsbaserte viten. Den er spontan og får oss gjennom dagen, og $90 \% \mathrm{av}$ vår viten/kunnskap er erfaringsbasert (15). For intensivsykepleierne var det viktig med nok teoretisk skolering med repetisjoner om inhalasjonssedering, og å øve tilstrekkelig på oppkobling av utstyr uten pasient. Å $\varnothing v e$ uten pasient vil kunne gi noen spontane, erfaringsbaserte handlingsmønstre i møte med reelle pasientsituasjoner. Når det oppstod noe uforutsett gjennomgikk de et spontant handlingsforløp både i hodet og kroppen for å kunne svare på situasjonen, i lys av Schöns forståelse av de erfaringsbaserte spontane handlingsmønstre. Viten/kunnskap i handling kan også kalles taus kunnskap - det er noe vi vet, men ikke alltid kan sette ord på (15). Ifølge Schön kan vi noen ganger beskrive den tause kunnskapen gjennom observasjon og refleksjon av handlingene våre. Men beskrivelsene beror på våre individuelle handlingsteorier: rekkefølger, prosedyrer, konklusjoner, regler, verdier, strategier og antagelser (15). Da blir tydelige prosedyrer for inhalasjonssedering viktige som statisk kunnskap for å st øtte de individuelle handlingsteoriene, mens tilgjengelig støttepersonell muliggjør at utviklingen av viten/kunnskap i handling fungerer dynamisk.

\section{Refleksjon underveis i øvelse uten pasient}

Verdien av $\varnothing$ velse uten pasient er et sentralt funn og er viktig for at intensivsykepleierne skal kunne tilegne seg viten/kunnskap i handling om inhalasjonssedering. Det innebærer også å reflektere i handling ut fra Schöns teori om den reflekterende praktikeren (15). Schön viser til refleksjon i handling som en bevegelig kunnskap, en refleksiv samtale med situasjonen (15). De starter med et utgangspunkt, så vurderer og eksperimenterer de for å finne bedre løsninger og finne flere nivåer av løsninger til de sitter igjen med en helt annen forståelse enn ved teoretisk undervisning. Det er også viktig å lære i et miljø med relativt lav risiko. Siden inhalasjonssedering som behandling brukes oftest til ustabile og komplekse pasienter, er øving uten pasient nødvendig før de kan begynne å $\varnothing v e$ på pasienter, der det også er rom for å reflektere i handlingssituasjonen. Hvis de ikke har nok ro og trygghet i akutte eller utfordrende situasjoner, greier de ikke å reflektere i situasjonen. Det er ikke alle situasjoner de kan reflektere i uansett hvor erfarne de er, men forutsetningene er bedre. Refleksjon i handling er et resultat av en uforutsett hendelse som de vurderer og agerer ut ifra, og som dermed utvikler viten/kunnskap i handling. Etterhvert kan de beherske denne egenskapen så godt at overgangene knapt er synlig (15).

\section{Refleksjon underveis i gjennomføring med pasient}

Funn i denne studien viser at intensivsykepleierne underveis må ha nok støtte, hjelp og informasjon for å gjennomføre inhalasjonssedering. Dette innebærer å få veiledning av ressurspersoner eller mer erfarne personer underveis, eller det å være to uerfarne som reflekterer i lag. Schön viser til at de må erverve seg egen praktisk erfaring, de lærer gjennom å utøve, før de oppnår viten/kunnskap i handling (15). Dette samsvarer med at de 
må bygge på den teoretiske undervisningen om inhalasjonssedering med praktisk læring for å oppnå viten/kunnskap i handling. Læringen skjer ved at de med mer erfaring med behandlingsmetoden viser og innfører de nye i de praktiske tradisjonene, ut fra Schön (15). Når behandlingsmetoden er ny for alle, blir det mer utfordrende i avdelingen. Da blir det nødvendig med en pragmatisk tilnærming, med å prøve og feile med behov for st $\varnothing t t e$ fra andre, det å være to sammen. Denne framgangsmåten er dog avhengig av refleksjon etter/over handling for å øke viten/kunnskapen i handling. Etter hvert som noen får erfaring, blir de veiledere for de andre. Da får en også automatisk flere kunnskapsnivåer innad i avdelingen som kan bygges videre på. Funn viser at intensivsykepleierne har en undring om de ikke bør ha litt erfaring først, før de blir lært opp på de mest komplekse behandlingsmetodene. Schön støtter denne undringen med at grunnlaget for å kunne reflektere både i og etter/over handlingen er viten/kunnskap i handling, den erfaringsbaserte kunnskapen (15).

Intensivsykepleierne erfarer at pasienten responderer på behandlingen. Da setter de egen utrygghet til side og gjennomfører inhalasjonssedering. Det innebærer at de gradvis får erfaring, og det hjelper dem videre. Med nok erfaring blir det like trygt som intravenøs sedasjon. Det kan sees ut fra Schöns teori som den reflekterende praktikeren, der det å oppnå viten/kunnskap i handling, det å reflektere i handlingssituasjonen og det å reflektere etter/over handlingssituasjonen bidrar til at de ser at pasienten responderer på behandlingen (15). De erfarer at pasienten har det bra med inhalasjonssedering, mye på grunn av at pasientene aksepterer behandlingen og har god effekt av den. Den gir en mer kontrollert situasjon, både respiratorisk og sirkulatorisk, og riktig sedasjonsnivå blir som oftest nådd. Jamfør Schön (15) må det være en god dynamikk mellom det å oppnå viten/ kunnskap i handling, det å reflektere $\mathrm{i}$ handlingssituasjonen og det å reflektere etter/over handlingssituasjonen for at det skal oppleves trygt. Et resultat av refleksjon blant de ansatte i denne avdelingen der informantene er hentet fra, er en revidert prosedyre for inhalasjonssedering som informantene beskrev som tilstrekkelig.

\section{Ulike kunnskapsformer og læring gjennom følelser og fornuft}

A oppnå ny viten/kunnskap i handling ved teoretisk skolering og refleksjon i handling med å $\varnothing v e$ uten pasient og refleksjon etter/over handling ved å gjennomføre inhalasjonssedering er veien de går for å bli trygg i utøvelsen. I lys av Aristoteles' kunnskapsformer oppnås teoretisk skolering gjennom intensivsykepleiernes tilgang til teoretisk opplæring/undervisning svarende til kunnskapsformen episteme, og ved å øve uten pasient oppnås ferdighetskunnskap, techne. Det legger grunnen for kunnskapsformen klokskap/ fronesis i selve ut $\varnothing v e l s e n$ av inhalasjonssedering av pasienten, den praktiske gjennomf $\varnothing$ ringen. Klokskap/fronesis som utvikles ved å gjennomføre inhalasjonssedasjon bygger på kunnskapsformene episteme og techne. De tre kunnskapsformene er i spill og sammen i refleksjonen og utøvelsen (16).

Videre viser funn at følelsen av trygghet og utrygghet hos intensivsykepleierne er sentral i utøvelsen av inhalasjonssedasjon. Det peker på Nussbaums (17) tenkning om 
at følelsene er intensjonale, rettet mot noe, driver personen til å handle og at følelsen har en vurderende holdning som kan endre en praksissituasjon gjennom utøvelse. I lys av det kan intensivsykepleiernes utrygghet og behovet for trygghet ved å inhalasjonssedere være følelser som er rettet mot situasjonen og driver dem til å handle der følelsene har en vurderende holdning og lener seg til fornuften i utøvelsen. Fornuften kan forstås som å ha rot i Aristoteles' kunnskapsformer epsisteme og techne, med teoretisk skolering og øvelse uten pasient, og kan fungere som et korrektiv når følelsen av utrygghet hos intensivsykepleiere overtar i situasjonene med å inhalasjonssedere pasientene.

\section{Studiens begrensninger og styrker}

Et begrenset utvalg som besto av seks informanter kan være mulige svakheter med studien. Studiens styrke er at deltagerne er rekruttert fra en større universitetsavdeling som har hatt en utøvende praksis på minst tre år med inhalasjonssedering. Informantene kunne med fordel ha vært rekruttert fra flere avdelinger for å gi bredde i funnene.

\section{Konklusjon}

Studien viser at intensivsykepleierne opplevde teoretisk undervisning sammen med praktisk øving uten pasient som nødvendig for å ut øve inhalasjonssedering til respiratorpasienter. Videre var det viktig å prøve og feile med støtte og hjelp underveis. Intensivsykepleiere kunne oppleve oppstarten som brå, de hadde ikke det i fingrene enda. Det å få støtte fra mer erfarne eller ressurspersoner var da viktig. Utfordringen med at dette var nytt for intensivsykepleierne, ble også noe mindre når de kunne være to som prøvde seg frem og reflekterte sammen. Gode behandlingsmål og retningslinjer fra legene og gode retningslinjer fra prosedyren gjorde også situasjonen tryggere.

Intensivsykepleierne opplevde at behandlingen med inhalasjonsgass administrert via AnaConDa til respiratorpasienter stort sett ga ønsket effekt for pasienten. Det motiverte dem til å fortsette å utøve for å bli trygge på bruken av AnaConDa.

\section{Implikasjoner for praksis}

Oppkobling, oppstart og administrering av behandling faller inn under intensivsykepleiernes ansvarsområde. Det viser viktigheten av at de behersker å utføre det, noe som igjen har betydning for respiratorpasientene. Det er viktig å prioritere teoretisk undervisning/ opplæring og øve praktisk uten pasient for å oppnå trygghet hos intensivsykepleierne. Deretter bør fokus flyttes til å utføre inhalasjonssedering på respiratorpasient der de er to intensivsykepleiere sammen når de er i oppstarten av implementering av inhalasjonssedering i en intensivavdeling. Eventuelt bør man sikre at de får st $\varnothing t t e$ fra mer erfarne eller ressurspersoner. Det å benytte en tilpasset simulering kan være et viktig supplement. Videre forskning kan være å unders $\varnothing$ ke hvilke erfaringer respiratorpasientene har med denne formen for sedering. 


\section{Referanser}

1. NSFs Landsgruppe av Intensivsykepleiere. NSFLIS, Bemanningsstandard for intensivsykepleie. 2015.

2. Sackey PV, Eriksson LI, Martling C-R, Radell PJ, Riou B. Case scenario: tailored sedation to the individual needs of the intensive care unit patient. Journal Am Soc Anesthesiol. 2010;113(6):1439-46. https://doi.org/10.1097/ALN.obo13e3181fcf5a7

3. Weavind LM, Saied N, Hall J, Pandharipande PP. Care bundles in the adult ICU: is it evidence-based medicine? Curr Anesthesiol Reports. 2013;3(2):79-88. https://doi.org/10.1007/s40140-013-0017-6ht

4. Dale CR, Kannas DA, Fan VS, Daniel SL, Deem S, Yanez III ND, et al. Improved analgesia, sedation, and delirium protocol associated with decreased duration of delirium and mechanical ventilation. Ann Am Thoracic Society. 2014;11(3):367-74. https://doi.org/10.1513/AnnalsATS.201306-210OCht

5. Ely EW, Shintani A, Truman B, Speroff T, Gordon SM, Harrell Jr FE, et al. Delirium as a predictor of mortality in mechanically ventilated patients in the intensive care unit. JAMA. 2004;291(14):1753-62. https://doi.org/10.1001/jama.291.14.1753

6. Veneman W, Reger M, Dirks R, Kaups K, Cullen C, Bennink C, et al. The smart approach to liberating trauma patients from mechanical ventilation and the ICU. Crit Care Med. 2019;47(1):32. https://doi. org/10.1097/01.ccm.0000550855.20886.a2

7. Pun BT, Balas MC, Barnes-Daly MA, Thompson JL, Aldrich JM, Barr J, et al. Caring for critically ill patients with the ABCDEF bundle: results of the ICU liberation collaborative in over 15,000 adults. Crit Care Med. 2019;47(1):3. https://doi.org/10.1097/CCM.0000000000003482ht

8. Sevin CM, Bloom SL, Jackson JC, Wang L, Ely EW, Stollings JL. Comprehensive care of ICU survivors: development and implementation of an ICU recovery center. J Crit Care. 2018;46:141-8. https://doi.org/10.1016/j.jcrc.2018.02.011

9. Torres J, Veiga C, Pinto F, Ferreira A, Sousa F, Jacinto R, et al. Post intensive care syndrome-from risk at ICU admission to 3 months follow-up clinic. Int Care Med Exp. 2015;3(1):1-2. https://doi. org/10.1186/2197-425X-3-S1-A448

10. van Beusekom I, Bakhshi-Raiez F, de Keizer NF, Dongelmans DA, van der Schaaf M. Reported burden on informal caregivers of ICU survivors: a literature review. Crit Care. 2015;20(1):16. https://doi. org/10.1186/s13054-016-1185-9

11. Mikkelsen ME, Netzer G, Iwashyna T. Post-intensive care syndrome (PICS). UptoDate; 2017. Tilgjengelig fra: https://www.uptodate.com/contents/post-intensive-care-syndromepics?source=related_link

12. Farrell R, Oomen G, Carey P. A technical review of the history, development and performance of the anaesthetic conserving device «AnaConDa» for delivering volatile anaesthetic in intensive and postoperative critical care. J Clin Monit Comput. 2018;32(4):595-604. https://doi.org/10.1007/s10877-0170097-9

13. Jerath A, Panckhurst J, Parotto M, Lightfoot N, Wasowicz M, Ferguson ND, et al. Safety and efficacy of volatile anesthetic agents compared with standard intravenous midazolam/propofol sedation in ventilated critical care patients: a meta-analysis and systematic review of prospective trials. Anesth Analg. 2017;124(4):1190-9. https://doi.org/10.1213/ANE.0000000000001634ht

14. Kim HY, Lee JE, Kim HY, Kim J. Volatile sedation in the intensive care unit: A systematic review and meta-analysis. Medicine. 2017;96(49). https://doi.org/10.1097/MD.0000000000008976ht

15. Schön DA. Uddannelse af den reflekterende praktiker: tiltag til en ny udformning af undervisning og læring for professionelle. Århus: Klim; 2013.

16. Aristoteles. Etikk. Et hovedverk i Aristoteles filosofi, også kalt «Den Nikomakiske etikk». Oversatt og med innledning av Anfinn Stigen. 2. utg. Oslo: Gyldendal; 1996.

17. Nussbaum M. Emotioner som värdeomdömen. I: Holm UM, Mark E, Persson A, red. Tanke, känsla, identitet. Gøteborg: Anamma Böcker; 1997. 
18. Thornquist E. Vitenskapsfilosofi og vitenskapsteori: for helsefag. Bergen: Fagbokforlaget; 2018.

19. Malterud K. Kvalitative forskningsmetoder for medisin og helsefag: en innføring. Oslo: Universitetsforlaget; 2017.

20. Gadamer H-G. Forståelsens filosofi. Oslo: Cappelen Akademiske Forlag; 1993.

21. Norsk senter for forskningsdata. https://nsd.no/personvernombud/

22. Kvale S, Brinkmann S, Anderssen TM, Rygge J. Det kvalitative forskningsintervju. 3. utg. Oslo: Gyldendal akademisk; 2015. 